\title{
Two Different Consumption Taxes Reflect the Price in Manufacturing Sector: An Analysis Using Input-Output Analysis
}

\author{
Siti Nur'amalina Syeddin*, Azman Hassan \\ School of Business and Economics University Putra Malaysia \\ *Corresponding Author: Siti Nur'amalina Syeddin, Department of Economics, Universiti Putra \\ Malaysia.
}

\begin{abstract}
The practice of Goods and Services Tax (GST) in 2015 is switch Sales and Services Tax (SST) has received various criticism due to the significant increase in prices of commodities especially in manufacturing sector. To contain this issue, the government has decided to replace GST with the former SST system effective on September 2018. However, this decision omits the representatives of industries with question regarding its impacts on the price level. This study is outlined to address this question by estimating the impacts of GST and SST rates on the price level through the production cost specifically on the manufacturing sector. Findings reveal that GST rates have the tendency to reduce the price level, which resulted in the price reduction for commodities under manufacturing sector. In contrast, SST is estimated to bring undesirable impacts for the price level. From the SST result, it shows that there were increased in price level of the commodities under manufacturing sector that lead to the prices increment. Nevertheless, the findings from this study does not reflect the real situation as the study only focus on the impacts of the consumption tax without considering the impacts of other cost-push components.
\end{abstract}

Keywords: Consumption tax structures, manufacturing sector, Input-Output Analysis.

\section{INTRODUCTION}

Effective on April 2015, GST is introduced at 6\% rate for selected goods and services particularly in the manufacturing sector. The practice of good and service tax (GST) replaces the former sales and services tax (SST) system that were introduced in February 1972 and March 1975, respectively. Dissimilar to the SST system, GST is a more comprehensive multi-stages tax system, which is commonly taxed on the consumption of goods and services at every stages of the supply chain. Currently, there are about 160 countries that have implemented GST.

The implementation of GST clearly refines the efficiency of taxation system that foster for national growth. Despite the efficiency of GST, there are concerns that revenue increases will negatively impact over the manufacturing industry. Price hikes on commodities is among the main question that arise during the GST practice which consequently affecting the production cost. In the literatures for instance, Dungan and Wilson (1989) and Gábriel and Reiff (2010) studies have shown several evidences that GST has contributed to economic prosperity, but in the same time, it also verges to rising in commodities prices.

Therefore, the government has decided to replace GST with the former SST system effective on September 2018 because of the price issue. However, this decision omits the members of industries with a question regarding its impacts on production cost in manufacturing sector. To address this question, this study is outlined to estimate the impacts of these two different consumption tax structures. Specifically, this study is established with the persistence:

- To estimate the impact of standard GST rates on the manufacturing sector.

- To assess the impact of SST rates on manufacturing sector.

Furthermore, this study applies the input-output modelling technique to analyse the impacts of GST and SST structures. The reason this technique is applied because of the capability in interpreting the interactions between production sectors. Moreover, this technique shows the relation among different production sectors which acquired commodities from other sectors as their production inputs and in 
turn, deliver commodities which are then sold to other sectors and to end consumers. The capability of input-output analysis to occupy the whole production interdependencies attends to the extensive application of the model for taxation impacts analysis (for some basic exposition on input-output analysis, see Miller and Blair, 2009).

This study is structured into four sections.

- Section 2 provides our main contribution to the scientific knowledge by reviewing relevant literatures.

- Section 3 presents methodologies for the estimation of impacts of GST and SST.

- Section 4 shows the main findings derived from the estimation.

- Section 5 provides the concluding remarks.

\section{LITERATURE REVIEW}

This section provides important findings from the literature which apprise the research gap in the area of consumption tax structures. Based on the literature survey, it revealeda main research gap of this study. The consumption tax structures studies in Malaysia are highly focused on the application of partial equilibrium techniques. Therefore, an applied general equilibrium analysis such as input-output model is more suitable to be applied as concerning to the economic and social impacts particularly on manufacturing sector. The following paragraphs detail of the literature survey.

A range of empirical studies on the consumption taxes have been organized to observe the economic and social impacts from the national level to specific regional and local level. For consumption tax structures itself, GST and SST are commonly found in empirical findings from studies around the world, especially in developing and developed countries (see for example, Gupta, 2014; Alm and ElGanainy, 2013; Keen and Lockwood, 2010). In the case of Malaysia, several studies on consumption tax structures include a number of works by Loganathan et al. (2017), Asmuni et al. (2017), Ling et al. (2016), Ramli et al. (2015) and Sanusi et.al. (2015). These are the national and local level studies that emphasize on the governance, compliance and acceptance aspects of GST that only study the impacts of GST implementation without considering the SST system. As a result of this literature gap, we are able to provide useful insights into the price impacts of the different consumption tax structures on the manufacturing sector.

In terms of methodology, studies in Malaysia are mostly conducted using partial equilibrium technique that is based on the econometric modelling approaches. For instance, Taha et. al. (2018) and Taha and Loganathan (2008) utilises the econometric modelling approach to look at the nexus between tax reformation, financial development and economic recovery. Meanwhile studies by Palil and Ibrahim (2011), Ishak et. al. (2015) and Shaari et. al. (2015) employs survey technique. The application of input-output model to study the consumption tax reforms in Malaysia is limited, with the exception of Hassan et. al. (2016). None of the studies used input-output model to study the impacts of consumption tax structures. This constitutes the literature gap that this paper aims to contribute to scientific knowledge.

\section{RESEARCH METHODOLOGY}

\subsection{Introduction}

This section provides the methodological approach used in this study. The methodology that is based on input-output modelling technique for impact analysis. In general, this section is outlined into three subsections.

- Subsection 3.2 details the framework of this study.

- Subsection 3.3 explains the input-output model for consumption tax structures study.

- Subsection 3.4gives the list of data utilised.

International Journal of Managerial Studies and Research (IJMSR)

Page | 112 


\subsection{Framework of the Study}

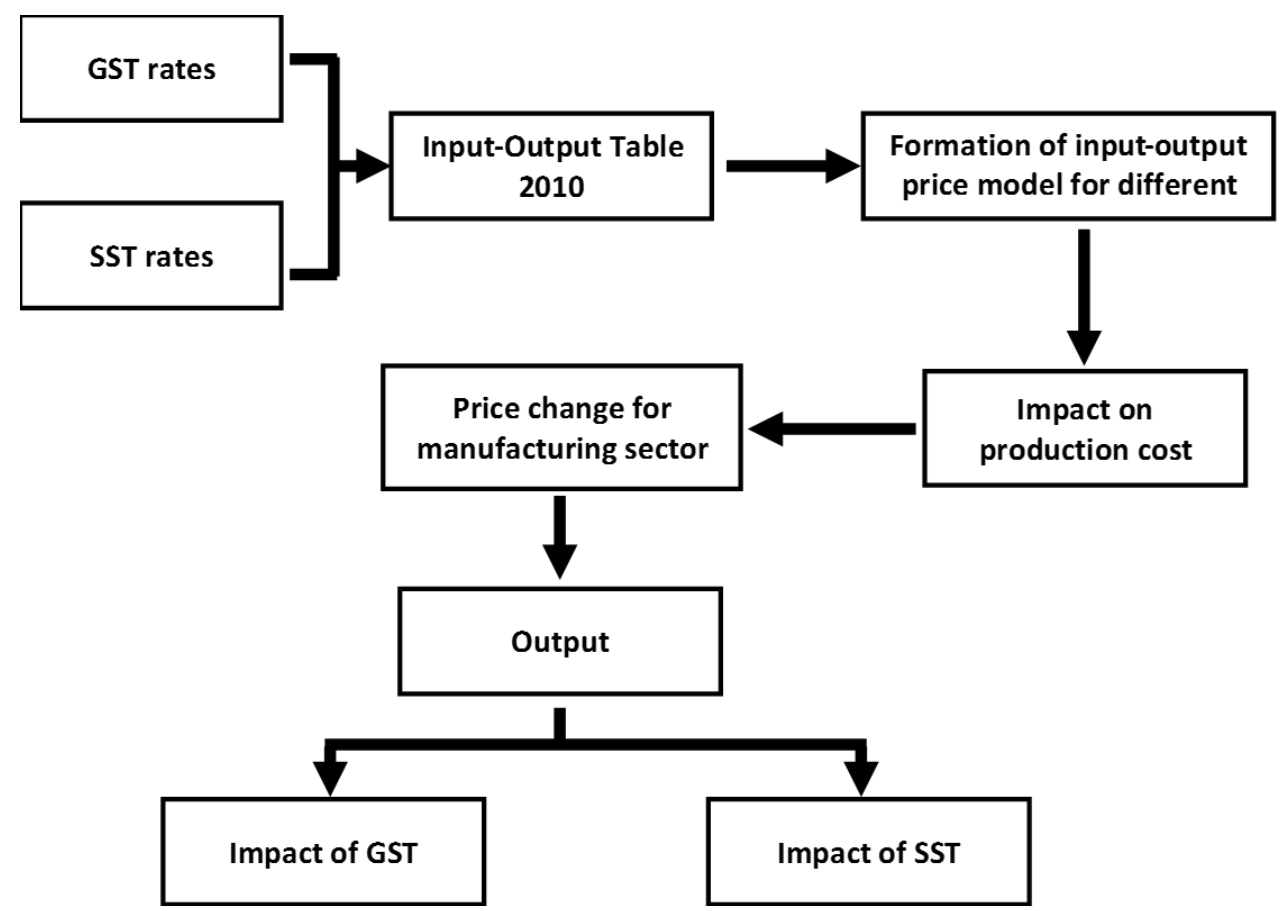

Figure3.1. Framework of the study

Based on Figure 3.1, the framework of this study can be summarised into four stages.

- The first stage of this study identifies the GST and SST variable in input-output table. Using the 2010 national input-output table, the variable can be found at the row of "taxes on products". In general, this variable refers to the amount of consumption tax paid by the industries to the government.

- Second, simulations on the impacts of GST rates and SST rates are undertaken. Each and every rate of GST and SST produce different impacts, thus the model developed needs to address this issue.

- In the third stage, the impacts of all consumption tax structures on cost of production are calculated to capture the changes in price level of each commodity under manufacturing sector. Two different models (GST and SST) are developed to analyse the impacts based on concept of price-pass through.

\subsection{Input-Output Price Model}

Input-output modelling technique is employed to estimate the impacts of the different consumption tax structures on the cost of production to capture the price changes. Such modelling approach is chosen as it has the capability to address the interdependency aspects among the production sectors. The interdependency can be expressed using the following equation.

$\mathbf{x}=\sum \mathbf{Z}+\mathbf{f}+\mathbf{e}$

where, $\mathbf{x}$ is the total output vector. Specifically, $\mathbf{x}$ is formed through the summation of output that is consumed as intermediate input $\mathbf{Z}$ (i.e. output of sector $\mathrm{A}$ that is used as intermediate input by sector B), output consumed by final demand, $\mathbf{f}$ (private household and government) and exports, e. In a standard model, equation (1) can be transformed into:

$\mathbf{x}=\mathbf{A x}+(\mathbf{f}+\mathbf{e})=(\mathbf{I}-\mathbf{A})^{-\mathbf{1}}(\mathbf{f}+\mathbf{e})=\mathbf{L}(\mathbf{f}+\mathbf{e})$

where, $\mathbf{I}$ is the identity matrix, $\mathbf{A}\left(\mathbf{A}=\mathbf{Z} \hat{\mathbf{x}}^{-\mathbf{1}}\right)$ is the input-output coefficient matrix, and $\mathbf{L}$ is the Leontief inverse matrix. For each sector, the Leontief inverse matrix coefficient represents the direct and indirect output that are required to fulfil each unit of final demand. Equation (2) is also known as input-output quantity model. This model assumes that only quantity changes, while price is fixed. 
Apart from quantity model, another input-output model is called price model. This model is useful to analyse impact of prices and costs such as taxes, import duty and labour income as it assumes that the quantity is fixed and prices and costs are adjustable. In short, prices are not perfectly elastic in this model (compared to prices are perfectly elastic in the quantity model). Price model can be summarised as follows:

$\mathbf{p}=\mathbf{A}^{\prime} \mathbf{p}+\mathbf{l}+\mathbf{v}+\mathbf{m}+\mathbf{t}$

$=\left(\mathbf{I}-\mathbf{A}^{\prime}\right)^{-\mathbf{1}}(\mathbf{I}+\mathbf{v}+\mathbf{m}+\mathbf{t})=\mathbf{L}^{\prime}(\mathbf{l}+\mathbf{v}+\mathbf{m}+\mathbf{t})$

where, pis a vector of normalized prices (price is adjusted to equal 1 at baseline), $\mathbf{A}^{\prime}$ is the transposed input-output coefficient matrix; and $\mathbf{l}, \mathbf{v}, \mathbf{m}$ and $\mathbf{t}$ are the column vectors for labour income coefficient (income per unit of output), capital income coefficient (capital income per unit of output), import coefficient (import per unit of output) and indirect taxes coefficient (indirect taxes per unit of output), respectively. In equation (3), $\mathbf{l}, \mathbf{v}, \mathbf{m}$ and tare exogenous variables. As we set $\mathbf{p}$ as unity, thus equation (3) can be simplified as the following:

$\mathbf{p}=\mathbf{L}^{\prime}(\mathbf{l}+\mathbf{v}+\mathbf{m}+\mathbf{t})$

Through equation $4, \mathbf{l}, \mathbf{v}$ and mare assumed to be fixed and only tis adjusted according to the GST and SST rates. It means that only $\mathbf{t}$ that causes change in $\mathbf{p}$. In this model, when there is no change in the indirect taxes, the represented indirect taxes coefficient is equal to 1 . Meanwhile, if indirect taxes have changed, the changes can be translated into: $\Delta \mathbf{t}=\mathbf{t} \otimes \Delta \mathbf{p}_{\mathbf{t}}$, where $\otimes$ refers to Hadamard product, which simply means cell-by-cell multiplication and $\Delta \mathbf{p}_{\mathbf{t}}$ refers to changes in indirect taxes. Therefore, the impact of changes in indirect taxes (such as GST and SST) on the prices of commodities of all economic sectors can be written as follow:

$\Delta \mathbf{P}=\mathbf{L}^{\prime}(\mathbf{l}+\mathbf{v}+\mathbf{m}+\Delta \mathbf{t})$

For GST, the modification on equation (5) is needed since the equation is modelled only for standard tax rate, but in practice, GST rates consist of $6 \%$, zero-rated and exempted rate. Each category of GST rates gives difference effects on the production cost directly to the price. Hence, the Leontief inverse matrix is modified according to the GST rates and modelled as in equation 6. For SST, the same process is also undertaken to address the dual tax rate (10\% and 6\%) for manufacturing and services.

$\Delta p=\left(I-A^{\prime} \widehat{B}\right)^{-1}(1+v+m+\Delta t)=L^{\prime}(1+v+m+\Delta t)$

Where,

$\widehat{\boldsymbol{B}}$ represents the diagonal matrix used to modify the input-output coefficient, $\mathbf{A}^{\prime}$ according to the GST and SST rates. Apart of $\mathbf{A}^{\prime}$, indirect tax coefficient, $\mathbf{t}$, are also adjusted for the impacts of GST as this consumption tax is based on value addition. The complete model for the impacts of GST and SST on the production cost is based on the following equation:

$$
\Delta p=\left(I-A^{\prime} \widehat{B}\right)^{-1}(1+v+m+u)=L^{\prime}(1+v+m+u)
$$

\subsection{Data Requirement}

This research utilises data from three main sources. The list of the data is given as the following:

- 2010 Input-Output Table (Department of Statistics Malaysia, 2014) This table is published by the Department of Statistics Malaysia (DOSM). The table is for 2010 base year and covers 124 production sectors.

- GST and SST rates (Royal Malaysian Customs Department, 2015 \& 2018) GST and SST rates for goods and services are obtained from the Royal Malaysian Customs Department.

\section{RESUlts FROM THE ANALYSIS}

To assess the impacts of different tax structures, input-output modelling technique is employed. However, before the price impact models are developed, two data processing stages are conducted. First, the list of goods and services that are classified using COICOP are matched with their relative taxation rate under each consumption tax structure. Following from this process, the output from stage one is mapped to the list of sectors in input-output table through MSIC 2008. The mapping allows 
Two Different Consumption Taxes Reflect the Price in Manufacturing Sector: An Analysis Using InputOutput Analysis

researchers to identify the composition of commodities in a sector which provides the baseline for price impacts modelling.

From the total 69 commodities under manufacturing sector, these commodities are classified into 9 categories of commodities. The average changes in the cost of production of these commodities are calculated to capture the price changes. Although not all sectors are taxed under both of the tax system, but the interdependency aspect that can be traced along the supply chain lead to the changes in cost of production in all sectors. In this case, the magnitude of the impacts depends entirely on the integration level between one sector to another. For example, both GST and SST system clearly defined that rice that is classified under Grain Mills commodity of manufacturing sector is exempted from consumption tax, but the interaction between the sector with other sectors in the supply chain has channelled some the impact to this sector.

\subsection{Impact of Consumption Taxes: Goods and Services Tax (GST) and Sales versus Services Tax (SST)}

This section emphasizes the findings from the analysis based on table 4.1. The table presents the impacts from the goods and services tax (GST) structure for 9 categories of commodities under manufacturing sector. In total GST is found to reduce the total price in the economy by $0.93 \%$. The highest reduction can be observed in food and non-alcoholic beverages with the estimated reduction by $2.71 \%$, followed by $1.21 \%$ in alcoholic beverages, tobacco, etc. while $1.07 \%$ reduction in clothing and footwear. This result is in-line with the findings highlighted in Hassan et. al. (2016) where the GST is also found to reduce the level of price. The reduction in their priceare mainly due to the facts that the commodities are levied with zero-rate GST.

Table4.1. GST structure impacts on 9 categories of commodities under manufacturing sector.

\begin{tabular}{|l|l|l|}
\hline \multirow{2}{*}{ Category } & \multicolumn{2}{l|}{ Weighted Average } \\
\cline { 2 - 3 } & \multicolumn{2}{|l|}{ Goods and Services Tax (GST) } \\
\cline { 2 - 3 } & Impact & Price Changes \\
\cline { 2 - 3 } & $\mathbf{( M Y R )}$ & $(\mathbf{\%})$ \\
\hline Food and non-alcoholic beverages & 0.97 & $(2.71)$ \\
\hline Alcoholic beverages, tobacco, etc. & 0.99 & $(1.21)$ \\
\hline Clothing and footwear & 0.99 & $(1.07)$ \\
\hline Housing, water and fuel & 1.00 & $(0.45)$ \\
\hline Furnishings, households equipment, etc. & 0.99 & $(0.59)$ \\
\hline Health & 1.00 & $(0.37)$ \\
\hline Transport & 1.00 & $(0.32)$ \\
\hline Recreation and culture & 0.99 & $(0.61)$ \\
\hline Miscellaneous goods and services & 0.99 & $(0.54)$ \\
\hline Total Economy & $\mathbf{0 . 9 9}$ & $\mathbf{0 . 9 3}$ \\
\hline
\end{tabular}

Note: Figures in parentheses refer to the price reduction.

Previous section reveals the price reduction for all of commodities under manufacturing sector due to the GST. Therefore, this section is evaluating the SST impact on the commodities under manufacturing sector. The results illustrated in table 4.2 indicated that the impacts of SST on the commodities is contrary to GST in which the price increment are estimated on the commodities under SST system. Findings from the analysis estimates the price increment of $14.70 \%$ of the total economy due to the SST. The highest increment can be noticed in clothing and footwear, food and nonalcoholic beverages and furnishings, households' equipment, etc. with the estimated increment of $15.75 \%, 15.74 \%$ and $15.59 \%$ respectively. The major reason behind the sharp rises in price level is due to the larger tax rate levied on manufacturers providers of $10 \%$.

Table4.2. SST structure impacts on 9 categories of commodities under manufacturing sector.

\begin{tabular}{|l|l|l|}
\hline \multirow{4}{*}{ Category } & \multicolumn{2}{l|}{ Weighted Average } \\
\cline { 2 - 3 } & \multicolumn{2}{|l|}{ Sales and Services Tax (SST) } \\
\cline { 2 - 3 } & Impact & Price Changes \\
\cline { 2 - 3 } & (MYR) & $(\%)$ \\
\hline Food and non-alcoholic beverages & 1.16 & 15.74 \\
\hline Alcoholic beverages, tobacco, etc. & 1.12 & 11.91 \\
\hline Clothing and footwear & 1.16 & 15.75 \\
\hline
\end{tabular}


Two Different Consumption Taxes Reflect the Price in Manufacturing Sector: An Analysis Using InputOutput Analysis

\begin{tabular}{|l|l|l|}
\hline Housing, water and fuel & 1.14 & 14.40 \\
\hline Furnishings, households equipment, etc. & 1.16 & 15.59 \\
\hline Health & 1.13 & 13.43 \\
\hline Transport & 1.13 & 13.04 \\
\hline Recreation and culture & 1.13 & 13.29 \\
\hline Miscellaneous goods and services & 1.14 & 14.47 \\
\hline Total Economy & $\mathbf{1 . 1 5}$ & $\mathbf{1 4 . 7 0}$ \\
\hline
\end{tabular}

With the assumptions that only consumption tax structures govern the price level in the economy, GST rates will reduce the price level by $0.93 \%$ in manufacturing sector. In specific, the largest price reduction is experienced by food and non-alcoholic beverages recorded the reduction of 2.71 per cent compared to other categories of commodity sectors. However, this situation is not being reflected in the economy as price level are partly determined by the subsidy rationalization, currency depreciation, minimum wage and monopolistic market structure. Meanwhile for the introduction of SST, the tax structure is prone to increase the total price by $14.70 \%$. Through SST rates, the largest price increase can be observed for clothing and footwear, food and non-alcoholic beverages and furnishings, households' equipment, etc. The major reason behind the sharp rises in price level is due to the larger tax rate levied on manufacturers of $10 \%$ compared to GST only $6 \%$.

\section{CONCLUSION}

This study documents findings from the estimation on the impacts of different consumption tax structures on the manufacturing sector in Malaysia. Based on the available dataset at the national level, the impacts are estimated by using the input-output modelling technique. This technique is supported by the available 2010 national input-output table. An input-output price model is developed to assess the impacts on the price changes of manufacturing sector.

Findings reveal that GST rates have the tendency to reduce the cost of production, which resulted in the reduction in the prices of commodities under manufacturing sector. In contrast, SST is estimated to bring undesirable impacts for cost of production and price level. With the input-output table suggests that the main type of commodity that impact more by these consumption taxes are on clothing and footwear, food \& non-alcoholic beverages and furnishings, households' equipment, etc., the increase in production cost of these categories of commodity under manufacturing sector will lead to the rising of price level.

Despite the usefulness of the findings from this study, the results need to be interpreted cautiously as the study is subjected to a number of assumptions. This study assumes that only consumption tax structures determine the price level through the production cost. This assumption leaves other forces such as subsidy rationalization, currency depreciation, minimum wage and monopolistic market structure as constant. To overcome the limitations, future works are proposed to look into such areas. This initiative is needed as the forces may have significant influence on both costs in the real life situation.

\section{REFERENCES}

[1] Alm, J., \& El-Ganainy, A. (2013) Value added taxation and consumption. International Tax and Public Finance, 20(1), 105-128.

[2] Asmuni, S., Yusoff, S., \&Ses, N. S. M. (2017). Acceptance towards Goods and Services Tax (GST) among local business communities. Journal of Emerging Economies \& Islamic Research, 5.

[3] Department of Statistics Malaysia. (2014). 2010 Input-Output Table. Department of Statistics Malaysia: Putrajaya.

[4] Dungan, D. P. \& Wilson, T. A., (1989). The proposed federal goods and services tax: its economic effects under alternative labour market and monetary policy. Canadian Tax Journal, 37, 341-367.

[5] Gabriel, P. \&Reiff, A. (2010). Price setting in Hungary: a store-level analysis. Managerial and Decision Economics, 31, 161-176.

[6] Gupta, N. (2014) Goods and services tax its impact on Indian economy. International Research Journal of Commerce Arts and Science, 5(3), 126-133.

[7] Hassan, A. A. G., Saari, M. Y., Utit, C., Hassan, A., \&Haron, M. (2016). PenggangaranImpak CBP keataskospengeluarandankossarahidup di Malaysia. Jurnal Ekonomi Malaysia, 50(2), 15-30. 
Two Different Consumption Taxes Reflect the Price in Manufacturing Sector: An Analysis Using InputOutput Analysis

[8] Ishak, N. I., Othman, M. H., \& Omar, M. F. (2015). Students' perception towards the newly implemented Goods and Services Tax (GST) in Malaysia. International Journal of Contemporary Applied Sciences, 2(6), 80-99.

[9] Keen, M., \& Lockwood, B., (2010). The value added tax: Its causes and consequences. Journal of Development Economics, 92(2), 138-151.

[10] Ling, S. C., Osman, A., Arman Hadi, A. B., Muhammad Safizal, A., \& Rana, S. M. (2016). Public acceptance and compliance on Goods and Services Tax (GST) implementation: A case study of Malaysia. Asian Journal of Social Sciences \& Humanities, 5(1), 1-12.

[11] Loganathan, N., Ismail, S., Streimikiene, D., Hassan, A. A. G., Zavadskas, E. K., \&Mardani, A. (2017). Tax Reform, Inflation, Financial Development and Economic Growth in Malaysia. Romanian Journal of Economic Forecasting, 20(4).

[12] Miller, R. E., and Blair, P. D. (2009). Input-output Analysis: Foundations and Extensions. Cambridge University Press.

[13] Palil, M. R., \& Ibrahim, M. A. (2011). The impacts of goods and services tax (GST) on middle income earners in Malaysia. World Review of Business Research, 1(3), 192-206.

[14] Ramli, R., Palil, M. R., Hassan, N. S. A., \& Mustapha, A. F. (2015). Compliance costs of Goods and Services Tax (GST) among small and medium enterprises. Journal of Management, 45.

[15] Royal Malaysian Customs Department (2015). Senarai Bekalan Berkadar Sifar, Dikecualik and an Pelepasan GST. Royal Malaysian Customs Department: Putrajaya.

[16] Royal Malaysian Customs Department (2018). Sales Tax (Goods Exempted from Tax) Order 2018. Royal Malaysian Customs Department: Putrajaya.

[17] Sanusi, S., Omar, N., \&Sanusi, Z. M. (2015). Goods and Services Tax (GST) Governance in the Malaysian New Tax Environment. Procedia Economics and Finance, 31, 373-379.

[18] Shaari, N., Ali, A., \& Ismail, N. (2015). Student's Awareness and Knowledge on the Implementation of Goods and Services Tax (GST) in Malaysia. Procedia Economics and Finance, 31, 269-279.

[19] Taha, R., \&Loganathan, N. (2008). Causality between tax revenue and government spending in Malaysia. The International Journal of Business and Finance Research, Vol. 2, No. 2, pp. 63-73.

[20] Taha, R., Šliogerienè, J., Loganathan, N., Jokšienè, I., Shahbaz, M., \&Mardani, A. (2018). The nexus between tax reformation, financial development and economic recovery: the case of Malaysia Technological and Economic Development of Economy, 24(3), 1258-127.

\section{AUTHORS’ BIOGRAPHIES}

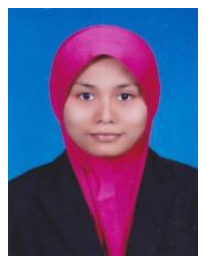

Siti Nur'amalina Syeddin, is Postgraduate Student in Department of Economics at University of Putra Malaysia. She previously worked as research assistant and enumerator for academic project in University of Putra Malaysia.

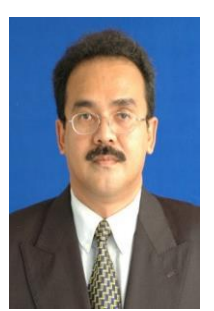

Azman Hassan, is Associate Professor in Department of Economics at University of Putra Malaysia. Azman is the author or coauthor of 15 journal articles. He worked for thirty-five years as a lecturer at School of Business and Economics.

Citation: Siti Nur'amalina Syeddin, Azman Hassan. "Two Different Consumption Taxes Reflect the Price in Manufacturing Sector: An Analysis Using Input-Output Analysis" International Journal of Managerial Studies and Research (IJMSR), vol 8, no. 7, 2020, pp. 111-117. doi: http:// dx.doi.org/10.20431/2349-0349.0807014.

Copyright: () 2020 Authors. This is an open-access article distributed under the terms of the Creative Commons Attribution License, which permits unrestricted use, distribution, and reproduction in any medium, provided the original author and source are credited. 